\section{Reduced Foliar Disease and Increased Yield of Pumpkin Regardless of Management Approach or Fungicide Combinations}

\author{
Kent E. Cushman ${ }^{1,9}$, William B. Evans², David M. Ingram³ \\ Patrick D. Gerard ${ }^{4}$, R. Allen Straw ${ }^{5}$, Craig H. Canaday ${ }^{6}$, \\ Jim E. Wyatt ${ }^{7}$, and Michael M. Kenty ${ }^{8}$
}

AdDitional INDEX WORDs. vine crops, Cucurbita spp., foliar phosphite, foliar nitrogen, potassium bicarbonate, powdery mildew, downy mildew, Sphaerotheca fuliginea, Erysiphe cichoracearum, Pseudoperonospora cubensis

SumMARY. Small- and large-scale farmers must often decide when to begin application of fungicides, either before the onset of disease as a preventative treatment or after disease becomes evident in the field. Growers also must decide about products that claim to enhance fungicide efficacy when added to the spray mixture. A study was conducted during the summer of 2002 to investigate control of foliar diseases of vine crops (Cucurbita spp.) with low-input (LI) or high-input (HI) management approaches and six fungicide/spray combinations at four locations in southeastern United States. Fungicide applications began for LI when leaf disease first became evident and for $\mathrm{HI}$ about 20 days after seeding. Both approaches continued applications at 7 - to 10 -day intervals until harvest. Spray treatments consisted of a water-only control or one of six combinations of azoxystrobin/chlorothalonil alone or in combination with potassium bicarbonate, foliar phosphite $(0 \mathrm{~N}-12.2 \mathrm{P}-21.6 \mathrm{~K})$, or foliar nitrogen $(25 \mathrm{~N}-0 \mathrm{P}-0 \mathrm{~K})$. Azoxystrobin was applied in rotation with chlorothalonil for all treatments except the control. Seeds of 'Lil' Goblin' pumpkin (Cucurbita pepo) were planted July to August and fruit harvested October to November, depending on location. Plants were rated twice for powdery mildew (Sphaerotheca fuliginea and Erysiphe cichoracearum) and downy mildew (Pseudoperonospora cubensis). HI did not significantly increase yield compared with LI. All fungicide treatments significantly increased yield and reduced foliar diseases compared with the water-only control. The simplest of treatments, the azoxystrobin/chlorothalonil rotation without any other chemicals, can be recommended for general use where strobilurin resistance has not been documented. ment of fungal diseases and subsequent yield loss. Two of the most important fungal diseases of cucurbits are powdery mildew (PM) and downy mildew (DM) (Zitter et al., 1996). These foliar diseases reduce fruit number, fruit quality, and the length of time crops can be harvested. Fungicide application to vegetable crops is generally preventive in nature rather than curative, and many states publish pesticide spray schedules for high-value crops. Thus, most fungicides are applied at a set schedule during some or all stages of a crop's production cycle or are applied based on integrated pest management models that forecast environmental conditions conducive to growth and infection by one or more pathogens. Models have been developed to forecast weather conditions favorable for disease occurrence such as TOM-CAST for tomato early blight (Alternaria solani), anthracnose (Colletotrichum coccodes), and septoria leaf spot (Septoria lycopersici) (Gleason et al., 1995) and cucurbit DM spore movement (Holmes et al., 2006). Some growers schedule sprays using these models and, as a result, often benefit from reduced fungicide applications and increased yield. However, adoption of these models by growers and consultants has been slow. Early application of fungicides has been shown to reduce gummy stem blight [Didymella bryoniae (synonym Mycosphaerella melonis)] in watermelon (Citrullus lanatus) compared with delayed applications, but differences in final spray date did not influence the area under the disease progress curve (Keinath, 2000). In a later paper, the same author reported fungicide scheduling
Company

Dr. Michael Kenty and James Thomas assisted with the study's design and implementation.

${ }^{1}$ Southwest Florida Research \& Extension Center, University of Florida, Institute of Food and Agricultural Sciences, Immokalee, FL 34142.

${ }^{2}$ Truck Crops Branch Experiment Station, Central Mississippi Research \& Extension Center, Mississippi State University, P.O. Box 231, Crystal Springs, MS 39059.

${ }^{3}$ Central Mississippi Research \& Extension Center, Mississippi State University, 1320 Seven Springs Road, Raymond, MS 39154.

${ }^{4}$ Experimental Statistics Unit, Mississippi State University, P.O. Box 9653, Mississippi State, MS 39762.

${ }^{5}$ Virginia Polytechnic Institute and State University, Southwest Virginia Agricultural Research and Extension Center, 12326 VPI Farm Road, Glade Spring, VA 24340.

${ }^{6}$ West Tennessee Research and Education Center, Entomology and Plant Pathology, University of Tennessee, Jackson, TN 38301.

${ }^{7}$ West Tennessee Research and Education Center, Plant Sciences, University of Tennessee, Jackson, TN 38301.

${ }^{8}$ Helena Chemical Co., 424 Quail Crest Drive, Collierville, TN 38017.

${ }^{9}$ Corresponding author. E-mail: kcushman@ufl.edu
$\mathrm{M}$ any areas of the United States produce cucurbits (Cucurbita spp.) for local and regional consumption. In the southeastern United States, weather is often conducive to the develop-

\begin{tabular}{llll}
\hline $\begin{array}{l}\text { Units } \\
\begin{array}{l}\text { To convert U.S. to SI, } \\
\text { multiply by }\end{array}\end{array}$ & U.S. unit & SI unit & $\begin{array}{l}\text { To convert SI to U.S., } \\
\text { multiply by }\end{array}$ \\
\hline 0.4047 & acre $(\mathrm{s})$ & $\mathrm{ha}$ & 2.4711 \\
102.7902 & acre-inch $(\mathrm{es})$ & $\mathrm{m}$ & 0.0097 \\
112.0851 & cwt/acre & $\mathrm{kg} \cdot \mathrm{ha}^{-1}$ & 0.0089 \\
73.0778 & $\mathrm{fl} \mathrm{oz} / \mathrm{acre}$ & $\mathrm{mL} \cdot \mathrm{ha}^{-1}$ & 0.0137 \\
0.3048 & $\mathrm{ft}$ & $\mathrm{m}$ & 3.2808 \\
3.7854 & $\mathrm{gal}$ & $\mathrm{L}$ & 0.2642 \\
9.3540 & $\mathrm{gal} / \mathrm{acre}$ & $\mathrm{L} \cdot \mathrm{ha}^{-1}$ & 0.1069 \\
1.1209 & $\mathrm{lb} / \mathrm{acre}$ & $\mathrm{kg} \cdot \mathrm{ha}^{-1}$ & 0.8922 \\
1.6093 & $\mathrm{mph}$ & $\mathrm{km} \cdot \mathrm{h}^{-1}$ & 0.6214 \\
28.3495 & $\mathrm{oz}$ & $\mathrm{g}$ & 0.0353 \\
6.8948 & $\mathrm{psi}$ & $\mathrm{kPa}$ & 0.1450 \\
1.1692 & $\mathrm{pt} / \mathrm{acre}$ & $\mathrm{L} \cdot \mathrm{ha}^{-1}$ & 0.8553 \\
2.3385 & $\mathrm{qt} / \mathrm{acre}$ & $\mathrm{L} \cdot \mathrm{ha}^{-1}$ & 0.4276 \\
$\left({ }^{\circ} \mathrm{F}-32\right) \div 1.8$ & ${ }^{\circ} \mathrm{F}$ & ${ }^{\circ} \mathrm{C}$ & $\left(1.8 \times{ }^{\circ} \mathrm{C}\right)+32$
\end{tabular}


increased marketable watermelon fruit yield and quality when the severity of gummy stem blight was high, but had little influence on yield or quality when severity was moderate or low (Keinath, 2001).

In addition to several common fungicides, several types of less traditional and potentially synergistic products are available. Phosphonic acid, phosphorus acid, or phosphonate fungicides used alone or in combination with traditional fungicides have been evaluated for the control of PM and DM in cucurbits and cole crops (Brassica spp.). Two such products, Biophos (Foliar Nutrients, Westminster, Colo.) and Phostrol (Nufarm Americas, Burr Ridge, Ill.) (Raid, 2005), reduced DM severity in chinese cabbage (Brassica rapa var. pekinensis) when used alone or in combination with mancozeb. Prophyt (Helena Chemical Co., Collierville, Tenn.), another P-based product, reduced the severity of DM of lettuce when used alone or with traditional fungicides (Raid and Meister, 2006). Potassium bicarbonate reduced the amount of PM on the upper leaf surface of muskmelon (Cucumis melo) (Turini et al., 2003). These products were reported to be systemic in plant tissue (Cooke and Little, 2001), but various plant species differ in their ability for uptake and distribution. Phosphonic acid compounds are reported to be effective against oomycete fungi by inhibiting oxidative phosphorylation (McGrath, 2004).

There is a paucity of information about fungicidal activity of other compounds primarily sold for foliar fertilizer use. Foliar nitrogen products, often composed of a slowrelease and proprietary mixture of urea, diurea, or methylene urea, have been reported to slightly increase lint yield of cotton (Gossypium hirsutum) (White et al., 1995). It is not known how a foliar $\mathrm{N}$ product will affect pumpkin yield or disease severity when combined with $\mathrm{K}$ and phosphite products and traditional fungicides in a disease management program.

Other researchers that have compared selected approaches to manage foliar diseases of vine crops have published similar conclusions-that is, fungicide application reduced disease severity compared with no fungicide application. This simple, but basic conclusion was reported regardless of the management approach under investigation-for example, a modeling approach for managing DM of pumpkin (Langston and Garner, 2001), a preventive fungicide spray schedule for controlling PM of squash (Cucurbita pepo) based on crop growth stage (Langston and Kelley, 2001), or an integrated pest management threshold method to schedule preventive applications for PM of pumpkin (McGrath, 2002). Results from such studies have produced varied results about which method of fungicide application would be best suited for managing foliar diseases of cucurbits, but all reported fungicide applications greatly improved vine growth, yield, and fruit quality compared with untreated controls.

Fungicide resistance management is an important aspect of any fungicide program for the control of foliar diseases of cucurbits. Benomyl, triadimefon (McGrath, 2001), and two strobilurin fungicides have been shown to control cucurbit PM inadequately in field research plots (McGrath, 1999). Fungicide-insensitive strains of the PM fungus developed after repeated use of the same product. Thus, any fungicide program to manage foliar diseases of cucurbits should use tank mixes or rotation of multiple products with different modes of action. The objective of this study was to compare low-input (LI) and high-input (HI) management approaches (early or delayed time of first application) with combinations of fungicide products to reduce losses associated with PM and DM on pumpkin.

\section{Materials and methods}

Plantings of pumpkin were established at two locations in Mississippi (Verona and Crystal Springs) and two in Tennessee (Crossville and Jackson) during Summer and Fall 2002. Two management approaches were compared in combination with six fungicide treatments and a water-only control. Management approaches were "low" or "high." LI consisted of foliar applications of fungicides beginning immediately after visual symptoms of leaf disease became evident and then continuing at 7 - to 10 -d intervals until 1 week before harvest. Plants were examined weekly for disease symptoms beginning 3 to 4 weeks after planting. HI consisted of foliar applications of fungicides beginning $20 \mathrm{~d}$ after seeding (DAS) and also continuing at 7 to 10-d intervals until 1 week before harvest. All fungicide treatments received azoxystrobin (Quadris; Syngenta Crop Protection, Inc., Greensboro, N.C.) in rotation with chlorothalonil (Equus 720; Griffin L.L.C., DuPont de Nemours and Co., Wilmington, Del.) each in a tap water solution. Azoxystrobin and chlorothalonil were applied at labeled rates, alone or in combination with potassium bicarbonate (Armicarb 100; Church \& Dwight, Princeton, N.J.), foliar phosphite [Ele-Max Foliar Phosphite 0-28-26 (0N12.2P-21.6K); Helena Chemical Co.], or foliar nitrogen [CoRoN 25-0-0 (25N-0P-0K); Helena Chemical Co. ]. Spray treatments consisted of a control, defined as a spray application of tap water, and six combinations of azoxystrobin/chlorothalonil alone or with various combinations of the previously mentioned foliar-applied chemicals (Table 1). The experimental design at each location was a randomized complete block with four replications and a $2 \times 7$ factorial arrangement of treatment combinations.

Raised beds were formed $15 \mathrm{ft}$ apart at Verona, Miss., Crossville, Tenn., and Jackson, Tenn.; and $10 \mathrm{ft}$ apart at Crystal Springs, Miss., centerto-center. Plots were $20 \mathrm{ft}$ long with plants spaced $2 \mathrm{ft}$ apart in the row, making a total of 10 plants per plot. Drip irrigation tubing, rated at 0.3 $\mathrm{gal} / \mathrm{min}$ per $100 \mathrm{ft}$ at $10 \mathrm{psi}$, was placed off center on the top of the bed. Preplant fertilizer was incorporated in the soil during bed formation at the rate of $50 \mathrm{lb} /$ acre N. Fertilizers supplying $\mathrm{P}$ and $\mathrm{K}$, and liming materials to adjust soil $\mathrm{pH}$, were applied according to soil tests and laboratory recommendations. Ammonium nitrate $\left(\mathrm{NH}_{4} \mathrm{NO}_{3}\right)$ sidedressing, supplying an additional $30 \mathrm{lb} /$ acre $\mathrm{N}$, was broadcast at Crystal Springs, Miss., and applied through the drip tubing at the other locations $\approx 25$ to 30 DAS.

'Lil' Goblin' (Harris Moran Seed Co., Modesto, Calif.), a cultivar 
Table 1. Products, application rates, and treatment combinations used in pumpkin experiments at two locations in Mississippi and one in Tennessee. Treatment combinations of fungicides and foliar-applied products were applied to pumpkin according to an LI approach on a 7 - to 10-d interval only after PM or DM became evident on foliage, or an $\mathrm{HI}$ approach on a 7 - to 10 -d interval beginning 20 DAS emergence regardless of evidence of disease.

\begin{tabular}{|c|c|c|c|c|c|c|c|c|}
\hline \multirow[b]{2}{*}{ Product $^{\mathrm{z}}$} & \multirow[b]{2}{*}{ Rate $^{y}$} & \multicolumn{7}{|c|}{ Treatment combinations } \\
\hline & & Control & 1 & 2 & 3 & 4 & 5 & 6 \\
\hline Azoxystrobin & $15.4 \mathrm{fl} \mathrm{oz} /$ acre & - & $\sqrt{ }$ & $\sqrt{ }$ & $\sqrt{ }$ & $\sqrt{ }$ & $\sqrt{ }$ & $\sqrt{ }$ \\
\hline Foliar nitrogen & $2.0 \mathrm{qt} /$ acre & - & - & $\sqrt{ }$ & - & - & - & $\sqrt{ }$ \\
\hline Potassium bicarbonate & $4.0 \mathrm{lb} /$ acre & - & - & - & $\sqrt{ }$ & - & $\sqrt{ }$ & $\sqrt{ }$ \\
\hline Foliar phosphite & $3.0 \mathrm{pt} / \mathrm{acre}$ & - & - & - & - & $\sqrt{ }$ & $\sqrt{ }$ & $\sqrt{ }$ \\
\hline
\end{tabular}

${ }^{2}$ Azoxystrobin (Quadris; Syngenta Crop Protection, Greensboro, N.C.) and chlorothalonil (Equus 720; Griffin L.L.C., DuPont de Nemours and Co., Wilmington, Del.) were applied in rotation: first azoxystrobin, then chlorothalonil, and then repeated in that order. The following products were also used: foliar nitrogen [CoRoN $25-0-0(25 \mathrm{~N}-0 \mathrm{P}-$ 0K); Helena Chemical Co., Collierville, Tenn.], potassium bicarbonate (Armicarb 100; Church \& Dwight, Princeton, N.J.), and foliar phosphite [Ele-Max Foliar Phosphite 0-28-26 (0N-12.2P-21.6K); Helena Chemical Co.].

${ }^{y} 1.0 \mathrm{fl} \mathrm{oz} / \mathrm{acre}=73.0778 \mathrm{~mL} \cdot \mathrm{ha}^{-1}, 1.0 \mathrm{pt} / \mathrm{acre}=1.1692 \mathrm{~L} \cdot \mathrm{ha}^{-1}, 1.0 \mathrm{qt} / \mathrm{acre}=2.3385 \mathrm{~L} \cdot \mathrm{ha} \mathrm{a}^{-1}, 1.0 \mathrm{lb} / \mathrm{acre}=1.1209 \mathrm{~kg} \cdot \mathrm{ha}{ }^{-1}$

characterized in one study as relatively susceptible to $\mathrm{DM}$ and $\mathrm{PM}$ (Stanghellini et al., 2003), was direct seeded 17 July 2002 (Verona, Miss.), 22 Aug. 2002. (Crystal Springs, Miss.), 31 July 2002 (Crossville, Tenn.), and 19 July 2002 (Jackson, Tenn.). Each hill was planted with two or three seeds. Ethalfluralin (except at Crystal Springs) and clomazone herbicides were applied immediately after seeding. After germination and emergence, hills were thinned by hand to one plant per hill 14 DAS. Row middles were mechanically cultivated with a tractormounted rototiller until vine growth prevented further cultivation. Active hives of honeybees (Apis mellifera) were placed within 0.25 mile of each planting to assist with pollination. When plants were relatively small, from emergence to about 2 feet in diameter, fungicide treatments were applied with 20 to $25 \mathrm{gal} /$ acre water, using a manually operated backpack sprayer (model 425; Solo, Newport News, Va.). When plants grew larger, treatments were applied with a motorized mist blower at Verona (model 444; Solo). At Crystal Springs, each fungicide treatment blend was applied using a $\mathrm{CO}_{2}{ }^{-}$ charged hand-held sprayer with four evenly spaced hollow-cone nozzles creating a 6 -ft-wide spray pattern. At all locations, plants were sprayed to ensure thorough coverage and penetration of the foliage but not to run off. Regardless of the sprayer used, the tank and boom were thoroughly rinsed between each application. Imidacloprid was applied as a soil drench 26 July 2002 at Verona, Miss. Additional insect controls were applied at labeled rates based on scouting at each location. At all locations, irrigation was applied through the drip tape so that, in combination with precipitation, the crop received at least 1.0 acre-inch of water per week.

Plants were rated twice for foliar diseases at each location between 45 and 75 DAS. Upper (adaxial) leaf surfaces of the center five plants of each plot were rated subjectively for percentage leaf area affected by PM and DM. This was a composite visual judgment that first estimated the relative number of leaves exhibiting disease symptoms and then estimated the relative leaf area of diseased leaves exhibiting symptoms. Together, a single number was determined for each plot and for each disease. Pumpkins were harvested from the center eight plants in each plot 2 Oct. 2002, 11 Nov. 2002, and 28 Oct. 2002 at Verona, Crystal Springs, and Crossville respectively. Fruit were graded as marketable or unmarketable (included immature, small, poor color, or rotting fruit), counted, and weighed. Yield data were statistically compared using PROC MIXED in SAS (SAS Institute, Cary, N.C.) with location as a random effect. Disease rating data were statistically compared in a similar manner, except time (first and second evaluations) was included in the model as a repeated measure.

\section{Results and discussion}

Growing conditions, plant nutrition, and insect control were generally good to excellent at all locations except Jackson, Tenn., where unusually wet conditions early during the growing season prevented application of all treatments. Severe DM followed that then led to total yield loss and, as a result, data from this location were dropped from the combined analysis. A 10-inch rain event at Crystal Springs, Miss., in late September (33 DAS) created an unusually challenging environment for disease control for a period of time, including a high risk for DM development along much of the Gulf of Mexico coast (Holmes et al., 2006). Plants at all locations exhibited symptoms of both DM and PM by the time of early fruit set. Signs of disease appeared at all locations within 40 to 50 DAS. The first LI spray was applied 55,46 , and 42 DAS at Verona, Crystal Springs, and Crossville respectively. The number of LI and HI spray applications was two and five, five and seven, and five and six at Verona, Crystal Springs, and Crossville respectively. LI saved an average of two spray applications across locations. Later in the growing season, many control plots were nearly completely defoliated and many of the treatment plots exhibited varying levels of PM and DM foliar symptoms (Fig. 1). The percentage of disease in control plots was 87 and 82 for PM and DM respectively, 75 DAS, leading to an almost complete defoliation at time of harvest (Table 2). All plots produced at least some marketable fruit.

There were no significant interactions between management approach and fungicide treatments for yield, fruit number, cull fruit, or average fruit weight (Table 3 ). Across locations, pumpkin yield and fruit number from $\mathrm{HI}$ averaged $21 \%$ greater than that of LI, but this difference 

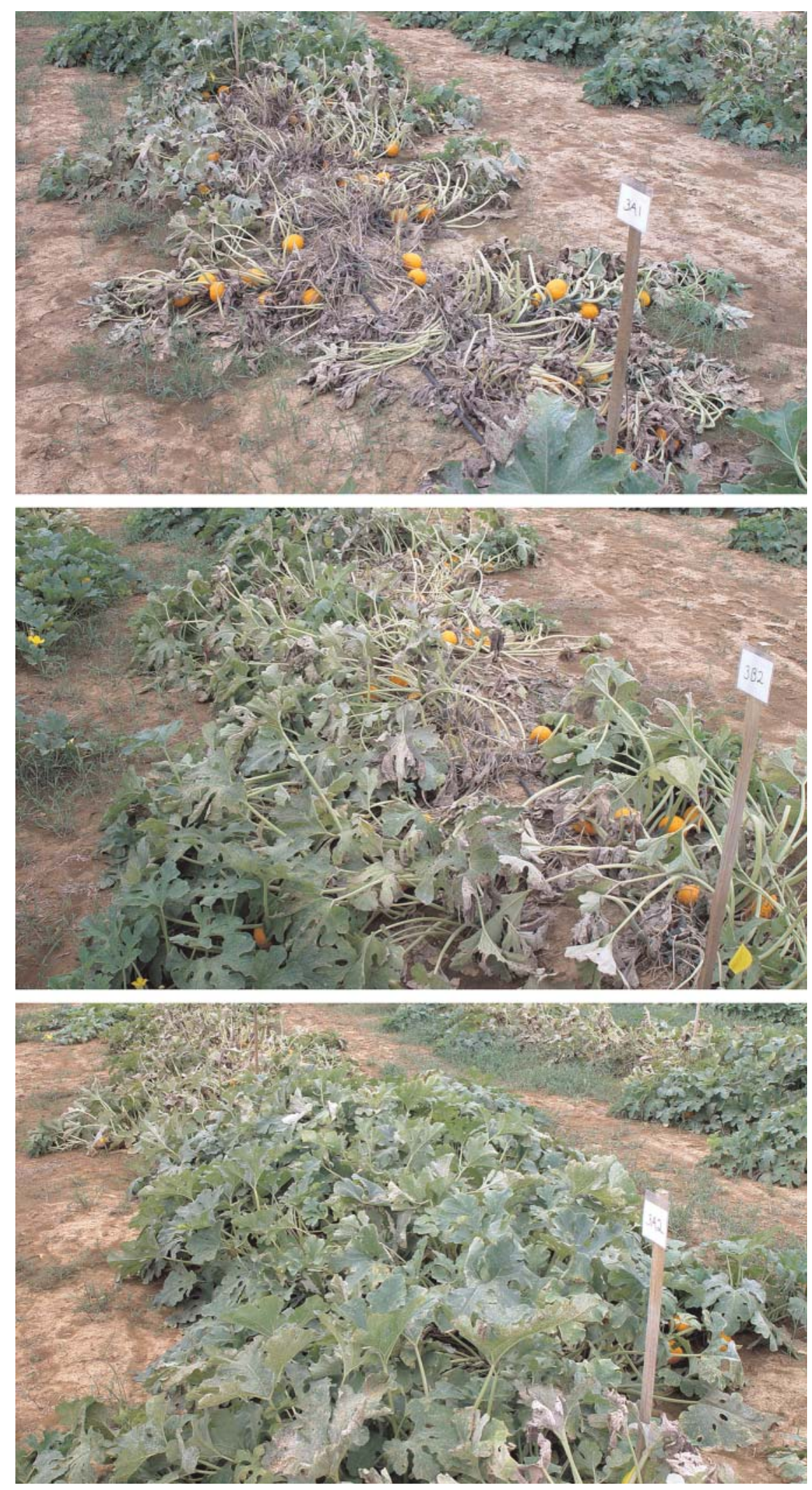

Fig. 1. View of pumpkin plants 1 week before harvest at the Verona, Miss., location. Fungicides were applied to each 10-plant plot according to an LI approach on a 7- to 10-d interval only after disease became evident on foliage, or on an HI approach on a 7 - to 10 -d interval beginning $20 \mathrm{~d}$ after seedling emergence. (top) Water-only control, no fungicides applied. (middle) LI approach, azoxystrobin/ chlorothalonil only. (bottom) HI approach, azoxystrobin/chlorothalonil only. was not statistically significant (Table 3). Fungicide treatments affected marketable yield and average marketable pumpkin weight, but only in comparison with the control. All six of the fungicide treatments produced significantly greater yields than the control by an average of $49 \%$ (number per acre) and $62 \%$ (hundredweight per acre). Among the six fungicide combinations, however, there were no significant differences in yield (number per acre and hundredweight per acre). Management approach or fungicide treatment did not affect number of culls, which averaged 890 culls / acre across all treatment combinations (Table 3 ).

Percentage of diseased foliage more than doubled from the first to the second observation regardless of the management approach (Table 2). PM ratings of LI foliage were almost double that of HI foliage for the first and second observations, but these differences were not statistically significant (Table 2). Similarly, DM ratings of LI foliage were higher than those of HI foliage for the first and second observations, respectively, but only the first rating was statistically significant. PM and DM ratings among the spray treatments were nonsignificant for each of the first observations, although there was almost a fivefold difference in PM ratings from a low of $11 \%$ to a high of $52 \%$ and more than a threefold difference in DM ratings from a low of $12 \%$ to a high of $37 \%$. Disease ratings for each of the second observations were significant, with PM ratings ranging from $32 \%$ to $87 \%$ and DM ratings ranging from $30 \%$ to $82 \%$. In each case, ratings for the untreated control were significantly greater than any of the six fungicide treatments, and among the six fungicide combinations there were no significant differences. There were no significant interactions between management approach, fungicide treatments, and time of rating.

Although the current work found no advantage to including potassium bicarbonate or foliar phosphite in a fungicide tank mix, there are reports of potassium carbonate, potassium bicarbonate, or potassium phosphite reducing fruit tree diseases (Reuveni et al., 2003). Potassium carbonate has been shown to reduce 
Table 2. Disease ratings of 'Lil' Goblin' pumpkin foliage at two locations in Mississippi and one in Tennessee during 2002. First and second ratings were made about 45 and $75 \mathrm{~d}$ after planting, respectively, at each location. Combinations of fungicides and foliar products were applied to pumpkin plants according to an LI approach on a 7 - to 10 -d interval only after disease became evident on foliage, or an $\mathrm{HI}$ approach on a 7 - to 10 -d interval beginning $20 \mathrm{~d}$ after seedling emergence.

\begin{tabular}{|c|c|c|c|c|}
\hline & \multicolumn{2}{|c|}{$\begin{array}{l}\text { Powdery mildew } \\
\text { rating }^{\mathrm{z}}(\%)\end{array}$} & \multicolumn{2}{|c|}{$\begin{array}{l}\text { Downy mildew } \\
\text { rating }^{\mathrm{z}}(\%)\end{array}$} \\
\hline & First & Second & First & Second \\
\hline \multicolumn{5}{|l|}{ Management approach } \\
\hline Low-input & 27 & 58 & $24 \mathrm{a}^{\mathrm{y}}$ & 62 \\
\hline High-input & 14 & 32 & $16 \mathrm{~b}$ & 38 \\
\hline \multicolumn{5}{|l|}{ Fungicide treatment ${ }^{\mathrm{x}}$} \\
\hline Control & 52 & $87 \mathrm{a}$ & 37 & $82 \mathrm{a}$ \\
\hline Azoxy/chloro & 22 & $45 \mathrm{~b}$ & 15 & $52 \mathrm{~b}$ \\
\hline Azoxy/chloro + N & 18 & $43 \mathrm{~b}$ & 29 & $55 \mathrm{~b}$ \\
\hline Azoxy/chloro $+\mathrm{KCO}_{3}$ & 12 & $33 \mathrm{~b}$ & 21 & $50 \mathrm{~b}$ \\
\hline Azoxy/chloro + P & 17 & $42 \mathrm{~b}$ & 12 & $30 \mathrm{~b}$ \\
\hline Azoxy/chloro $+\mathrm{KCO}_{3}+\mathrm{P}$ & 11 & $32 \mathrm{~b}$ & 14 & $45 \mathrm{~b}$ \\
\hline Azoxy $/$ chloro $+\mathrm{N}+\mathrm{KCO}_{3}+\mathrm{P}$ & 13 & $32 \mathrm{~b}$ & 12 & $34 \mathrm{~b}$ \\
\hline \multicolumn{5}{|l|}{ Significance } \\
\hline Management & 0.375 & 0.303 & 0.005 & 0.407 \\
\hline Fungicide & 0.140 & $<0.001$ & 0.293 & 0.027 \\
\hline Management $\times$ fungicide & 0.555 & 0.513 & 0.528 & 0.151 \\
\hline
\end{tabular}

${ }^{2}$ Values of disease ratings are means of four replications of the center five plants per replication. Subjective ratings of percentage leaf area affected by foliar diseases.

Values in columns followed by the same lowercase letter, are not significantly different at $P \leq 0.05$.

x Fungicides were applied in rotation-azoxystrobin (Azoxy) first then chlorothalonil (chloro) - and were then repeated in that order. Other treatments included foliar nitrogen [ $\mathrm{N}$; CoRoN $25-0-0(25 \mathrm{~N}-0 \mathrm{P}-0 \mathrm{~K})$; Helena Chemical Co., Collierville, Tenn.), potassium bicarbonate ( $\mathrm{KCO}_{3}$; Armicarb 100; Church \& Dwight, Princeton, N.J.), and foliar phosphite [P; Ele-Max Foliar Phosphite 0-28-26 (0N-12.2P-21.6K); Helena Chemical Co.]. spore germination and kill germ tubes in apple scab (Venturia inaequalis) (Schulze and Schönherr, 2003), although we can find no reports of disease reduction from these products in cucurbits.

In summary, our results indicate that $\mathrm{HI}$, which involved the application of fungicides beginning 20 DAS and continuing at 7 - to 10 -d intervals until harvest, increased yield and decreased disease ratings numerically but not significantly compared with LI, which involved the application of fungicides beginning at the first visible indication of leaf disease and continuing weekly until harvest. There were an average of four spray applications for LI and six for HI, a 50\% increase in the number of applications. It is clear from our results that either of the two management approaches and any of the six fungicide treatments were superior to the water-only controls. Therefore, the simplest of the treatments, the azoxystrobin/chlorothalonil rotation without any of the other chemicals added to the spray solution, can be recommended for general use. The other products tested neither enhanced nor detracted significantly from the efficacy of the fungicides

Table 3. Marketable and unmarketable pumpkins of 'Lil' Goblin' and average weight from two locations in Mississippi and one in Tennessee during 2002. Combinations of fungicides and foliar products were applied to pumpkin plants according to a low-input (LI) approach on a 7- to 10-d interval only after disease became evident on foliage, or a high-input (HI) approach on a 7 - to 10 - $\mathrm{d}$ interval beginning $20 \mathrm{~d}$ after seedling emergence.

\begin{tabular}{|c|c|c|c|c|}
\hline & \multicolumn{2}{|c|}{ Pumpkin yield ${ }^{\mathrm{z}}$} & \multirow{2}{*}{$\begin{array}{c}\begin{array}{c}\text { Culls } \\
\text { (no./acre })^{\mathrm{x}}\end{array} \\
\end{array}$} & \multirow{2}{*}{$\begin{array}{l}\text { Avg. pumpkin } \\
\text { wt. }^{y}(1 b)^{x}\end{array}$} \\
\hline & $(\text { no. } / \text { acre })^{\mathrm{x}}$ & $(\mathrm{cwt} / \mathrm{acre})^{\mathrm{x}}$ & & \\
\hline \multicolumn{5}{|l|}{ Management approach } \\
\hline High-input & 12,500 & 14.1 & 870 & 1.10 \\
\hline \multicolumn{5}{|l|}{ Fungicide treatment $\mathrm{t}^{\mathrm{w}}$} \\
\hline Control & $8,000 \mathrm{~b}^{\mathrm{v}}$ & $8.4 \mathrm{~b}$ & 840 & $0.98 \mathrm{~b}$ \\
\hline Azoxy/chloro $+\mathrm{KCO}_{3}$ & $11,600 \mathrm{a}$ & $13.3 \mathrm{a}$ & 850 & $1.11 \mathrm{a}$ \\
\hline Azoxy/chloro $+\mathrm{P}$ & $12,200 \mathrm{a}$ & $14.2 \mathrm{a}$ & 980 & $1.17 \mathrm{a}$ \\
\hline Azoxy/chloro $+\mathrm{KCO}_{3}+\mathrm{P}$ & $12,000 \mathrm{a}$ & $13.7 \mathrm{a}$ & 830 & $1.12 \mathrm{a}$ \\
\hline Azoxy/chloro $+\mathrm{N}+\mathrm{KCO}_{3}+\mathrm{P}$ & $12,900 \mathrm{a}$ & $14.1 \mathrm{a}$ & 1160 & $1.07 \mathrm{a}$ \\
\hline \multicolumn{5}{|l|}{ Significance } \\
\hline
\end{tabular}


under the conditions of this study. Ratings of PM and DM disease symptom development support these conclusions. Expenses associated with scouting or additional spray applications must also be considered when deciding between the LI and HI approaches.

\section{Literature cited}

Cooke, L.R. and G. Little. 2001. The effect of foliar application of phosphonate formulations on the susceptibility of potato tubers to late blight. Pesticide Mgt. Sci. 58:17-25.

Gleason, M.L., A.A. MacNab, R.E. Pitblado, M.D. Ricker, D.A. East, and R.X. Latin. 1995. Disease-warning systems for processing tomatoes in eastern North America: Are we there yet? Plant Dis. 79:113-121.

Holmes, G., C. Main, T. Keever, M. Miller, and P. Pyle. 2006. North American plant disease forecast center. Cucurbit downy mildew. 25 May 2006. $<$ www.ces.ncsu.edu/depts/pp/cucurbit/>.

Keinath, A.P. 2000. Effect of protectant fungicide application schedules on gummy stem blight epidemics and marketable yield of watermelon. Plant Dis. $84: 254-260$

Keinath, A.P. 2001. Effect of fungicide applications scheduled to control gummy stem blight on yield and quality of watermelon fruit. Plant Dis. 85:53-58.
Langston, D.B., Jr. and J.C. Garner. 2001. Evaluation of fungicides for control of downy mildew of pumpkin, 2000 . Fungicide Nematicide Tests 56:V72.

Langston, D.B. and W.T. Kelley. 2001. Evaluation of fungicides and foliar biological control materials for control of powdery mildew in transgenic yellow crookneck squash, 2000. Fungicide Nematicide Tests 56:V90.

McGrath, M.T. 1999. Evaluation of biocompatible products for managing cucurbit powdery mildew. Crop Prot. 18:471478.

McGrath, M.T. 2001. Fungicide resistance in cucurbit powdery mildew: Experiences and challenges. Plant Dis. 85:236-245.

McGrath, M.T. 2002. Evaluation of fungicide programs for managing powdery mildew of pumpkin, 2001. Fungicide Nematicide Tests 57:V086.

McGrath, M.T. 2004. What are fungicides? The plant health instructor. 7 July 2006. <www.apsnet.org/education/ IntroPlantPath/Topics/fungicides / default.htm>

Raid, R.N. 2005. Comparison of phosphonic foliar applications for control of downy mildew of chinese broccoli, 2004. Fungicide Nematicide Tests 60:V116.

Raid, R.N. and C. Meister. 2006. Evaluation of foliar fungicides alternated with Prophyt for control of lettuce downy mildew, spring 2005. Fungicide Nematicide Tests 61:V093.
Reuveni, M., D. Sheglov, and Y. Cohen. 2003. Control of moldy-core decay in apple fruits by beta-aminobutyric acids and potassium phosphites. Plant Dis 87:933-936.

Schulze, K. and J. Schönherr. 2003. Calcium hydroxide, potassium carbonate and alkyl polyglycosides prevent spore germination and kill germ tubes of apple scab (Venturia inaequalis). J. Plant Dis. Prot. 110:36-45.

Stanghellini, M.S., J.R. Schultheis, and G.J. Homes. 2003. Adaptation and market potential of jack o'lantern and miniature pumpkin cultivars in eastern North Carolina. HortTechnology 13:532-539.

Turini, T.A., M.D. Coffey, and J. Aguiar. 2003. Comparison of fungicides for control of powdery mildew on muskmelon, 2003. Fungicide Nematicide Tests 59:V096.

White, D.R., S.G. Morse, D.M. Oosterhuis, and E.M. Holman. 1995. The effects of foliar-applied controlled release nitrogen on uptake and yield of cotton in Arkansas. Proc. Beltwide Cotton Conf, Natl. Cotton Council, Memphis, Tenn. p. 1355-1356.

Zitter, T.A., D.L. Hopkins, and C.E. Thomas (eds.). 1996. Compendium of cucurbit diseases. Amer. Phytopathol. Soc., St. Paul, Minn. 